\title{
ARTICLE \\ Unamuno on making oneself indispensable and having the strength to long for immortality
}

\section{Adam Buben ${ }^{1}$ (iD}

Received: 1 August 2020 / Accepted: 18 February 2021 / Published online: 5 March 2021

(c) The Author(s) 2021

\begin{abstract}
Unamuno believes that longing for immortality is what motivates nearly all of human behavior. Unfortunately, in a world in which many people despair of ever achieving true personal immortality, we increasingly turn to what he calls mere "shadows of immortality" for comforting ideas about how our names, energy, or basic material substance will carry on in our absence. Unamuno advocates fighting against such despair, staying out of the shadows, and longing for personal immortality even when it seems impossible. Unamuno's approach to this issue resembles, in a few significant ways, Kierkegaard's struggle for the cultivation of subjective selfhood. At the same time, it also runs afoul of Nietzsche's derisive claims about immortality-seekers. Whereas Nietzsche sees longing for immortality as a sign of being too weak to make the most of mortal life, the more Kierkegaardian Unamuno counters that it is a sign of strong appreciation for life to demand, without surrender, that there be more of it. Given the proper understanding of Nietzsche's claims about the eternal recurrence, I think he and Unamuno might not be quite as far apart as it initially seems. However, exploring the latter's critique of the former suggests an intriguing way of seeing the contemporary analytic debate about the desirability of immortality. Building on Unamuno's position, one could argue that pessimism about the value of immortality is actually indicative of a flawed character and an impoverished relationship with life.
\end{abstract}

Keywords Kierkegaard $\cdot$ Meaning $\cdot$ Nietzsche $\cdot$ Self $\cdot$ Williams

Adam Buben

a.j.buben@luc.leidenuniv.nl

1 Leiden University, Leiden University College, Anna van Buerenplein 301, 2595 DG The Hague,

The Netherlands 


\section{Introduction}

In The Tragic Sense of Life, Miguel de Unamuno claims that longing for immortality is what motivates nearly all of human behavior. However, in a world in which many people despair of ever achieving true personal immortality, they increasingly turn to cheap imitations of immortality for comforting ideas about how our names, energy, or basic material substance will carry on in our absence. Unamuno (1954, p. 265) advocates fighting against such despair, staying away from the imitations, and longing for personal immortality even when it seems impossible: "he above all deserves immortality who desires it passionately and even in the face of reason." These ideas are somewhat at odds with the views of those John Martin Fischer (see e.g. 2009) has amusingly called the "immortality curmudgeons." The curmudgeons are mostly analytic-style philosophers who argue, for one reason or another, that an immortal life would not be worth living. While a few of these thinkers comment on their disagreement with Unamuno, it is unfortunate that Unamuno never got the chance to return the favor. With the help of two earlier philosophers, Søren Kierkegaard and Friedrich Nietzsche, whom Unamuno did have a chance to encounter and write about, I will be able to clarify how exactly he might fit into the contemporary desirability of immortality debate. Ultimately, I will make the case that Unamuno would see a curmudgeonly attitude toward immortality as indicative of a flawed character and an impoverished relationship with life.

\section{What we really want}

In making assertions such as "Nothing is real that is not eternal," Unamuno (1954, p. 39) sounds a lot like the Socrates of Plato's Phaedo (cf. Candelaria, 2012, p. 49). And like that version of Socrates (see e.g. Plato, 2002, 66b-66e), he also sees a clear connection between a life's meaning and what happens to a person at its conclusion. As one commentator puts it, "For Unamuno there is no meaning in this life if there is not another life in which the self he currently is remains" (Evans, 2013, p. 101; cf. p. 48). ${ }^{1}$ In Unamuno's (1954, pp. 42-44) own words:

If at the death of the body which sustains me...my consciousness returns to the absolute unconsciousness from which it sprang, and if a like fate befalls all my brothers in humanity, then is our toil-worn human race nothing but a fatidical procession of phantoms, going from nothingness to nothingness...If we all die utterly, wherefore does everything exist?...it is the Wherefore that corrodes the marrow of the soul...our thirst of immortality, of survival, will always stifle in us this pitiful enjoyment of the life that passes and abides not.

This tethering of the hope for personal meaning to the prolongation of the person suggests that Unamuno would be an enthusiastic advocate of what Thaddeus Metz

\footnotetext{
${ }^{1}$ A number of other commentators make similar claims: see e.g. Ariso (2017, p. 91) and Culpepper (1961, p. 280).
} 
(2003) calls “The Immortality Requirement for Life's Meaning.” Such a requirement might seem easy to criticize at first glance, but before any possible criticisms of Unamuno's position can be properly considered, the nature of this enthusiasm for immortality must be more thoroughly explained. ${ }^{2}$

Unamuno (1954, p. 41) believes that every human being longs for immortality, and he cites the ubiquity of commemorative rituals and religious traditions as evidence supporting this belief. We simply cannot tolerate the notion that we will be entirely swallowed up by nothingness. It is not pride, however, that drives this intolerance, "but terror of extinction" (Unamuno, 1954, p. 57; cf. p. 47). Unamuno (1954, pp. 43-44) even claims that total annihilation is more abhorrent to him than the everlasting torments of hell: "It is better to live in pain than to cease to be in peace." 3 But even those who do not share this rather extreme, and perhaps naïve, sentiment, would have to admit that many of their attitudes and behaviors seem directed toward their own preservation in some form or another. ${ }^{4}$ In the modern world, where traditional beliefs about the immortality of the soul often no longer seem viable, people still have children and create works of art and literature in the hopes of passing on a genetic legacy or etching their names in the history books. We may not always be fully cognizant of the nature of these hopes, but Unamuno sees them all as manifestations of the human hunger for immortality. He states, "When doubts invade us and cloud our faith in the immortality of the soul, a vigorous and painful impulse is given to the anxiety to perpetuate our name and fame, to grasp at least a shadow of immortality" (Unamuno, 1954, p. 52; cf. pp. 46, 51, 55-56). One other "shadow" Unamuno (1954, pp. 46-47, 57) considers is the tendency of certain religious and philosophical worldviews to offer comfort in the face of personal annihilation through pan(en)theistic or monistic "tricks" that promise preservation in the all-encompassing mind of God, or conservation of mass and energy in the universe. ${ }^{5}$ What all of these "shadows" have in common is that they just do not get

\footnotetext{
2 Ben Bradley (2015, pp. 413-417) briefly mentions Unamuno's "immortality or bust" attitude while making his case that permanence is not a necessary condition for meaning in life. I am somewhat sympathetic to Bradley's argument, but I think he is insufficiently sensitive to the ways necessary impermanence can trivialize and introduce other complications into the meaning we often uncritically attribute to our activities and accomplishments. Thus, I am not convinced his argument would provide a decisive counter to a more nuanced reading of Unamuno's view.

3 This idea seems to have been a recurrent theme throughout Unamuno's work (see Culpepper, 1961, p. 288).

4 People who commit suicide seem like obvious counterexamples to Unamuno's claims about both the universality of longing for immortality, and the preference for a life of pain over absolute nonexistence. While I am not sure the latter claim is entirely defensible, since some suffering might just be unbearable (cf. Luper-Foy, 1993, p. 269n1), Unamuno does think suicide can be explained within the framework of a universal longing for immortality. He says, "it is the supreme longing for life, for more life, the longing to prolong and perpetuate life, that urges [suicidal individuals] to death, once they are persuaded of the vanity of this longing" (Unamuno, 1954, pp. 44-45). In other words, suicide is one possible response when people become convinced that immortality is unlikely. As I have already shown, without the hope of more to come, Unamuno thinks the value of this life is diminished.

5 In discussing these ideas, Unamuno explicitly mentions the Upanișads, which are among the ancient Indian texts Arthur Schopenhauer (1958, pp. 475, 491-492, 499, 507-508) uses to support his similar views about the durability of an impersonal reality and the transient insignificance of human individuality (cf. Olivelle, 2008, Bṛhadāranyaka 4.4, Kața 2). As for Unamuno himself, even in his more pan(en)
} 
at what we really want when we grow nervous about our impending annihilation (cf. Candelaria, 2012, pp. 55-56). It is for this reason that one might refer to them as "consolation prizes." 6

What we really want, when we are desperately trying to preserve something of ourselves through any means available, is personal immortality. As Unamuno (1954, p. 45) famously puts it, "I do not want to die-no; I neither want to die nor do I want to want to die; I want to live for ever and ever and ever. I want this 'I' to livepoor 'I' that I am and that I feel myself to be here and now, and therefore the problem of the duration of my soul, of my own soul, tortures me." It is worth noting that, although he frequently speaks of the soul, which suggests a desire for immortality in some kind of an afterlife that only God can provide (cf. Candelaria, 2012, p. 49), there is nothing in this passage that clearly rules out the kind of technologically achieved life-extension that many optimistic futurists hope for. In fact, if Unamuno had known about cryonics, cyborgization, nanotechnology, and the types of medical interventions hypothesized these days (cf. Agatonović, 2018, p. 430), he may very well have been on board. ${ }^{7} \mathrm{He}$ seems to be a strong advocate for bodily longevity (see e.g. Unamuno, 1954, p. 47; cf. Culpepper, 1961, p. 285), and unlike the Socrates of Plato's Phaedo (see e.g. Plato, 2002, 118a), he does not seem all that opposed to continuing on in something like worldly life. Unamuno (1954, p. 231) states, "What we really long for after death is to go on living this life, this same mortal life, but without its ills, without its tedium, and without death." Since many of the medical/technological interventions proposed by optimistic futurists are meant to eliminate life's various ills, and thinkers such as Fischer (2009), Sophie-Grace Chappell (2007), and J. Jeremy Wisnewski (2005) have convincingly argued that tedium need not be a serious concern in lives of any length, it seems plausible that the kind of immortality/life-extension Unamuno describes can be desired by the religious and the irreligious alike.

\section{Death and injustice}

Of course, whether or not the technological limitations of his era are part of the explanation, Unamuno simply does not place his hopes for personal immortality in scientific advancement. From his conflicted religious perspective, science, and reason in general, seem to work against these hopes (cf. Baker, 1990, p. 44; Evans, 2013, p. 50; Weinstein, 1976, p. 47). According to Unamuno (1954, pp. 103-104; cf. p. 90),

\section{Footnote 5 (continued)}

theistic or monistic moments, he is always careful to make sure "the personal identity is not lost" (Baker, 1990, p. 52; cf. Culpepper, 1961, p. 293).

${ }^{6}$ Despite his criticisms of these consolation prizes, Unamuno is not entirely immune to their temptations; he occasionally gets wrapped up in trying to live on through his work (see Evans, 2013, p. 46; Franz, 1980, p. 652).

7 It is not as clear to me that he would have been so interested in mind-uploading, but I cannot rule it out. 
It must remain established...that reason-human reason-within its limits, not only does not prove rationally that the soul is immortal...it proves rather... that the individual consciousness cannot persist after the death of the physical organism upon which it depends. And these limits, within which I say that human reason proves this, are the limits of rationality, of what is known by demonstration. Beyond these limits is the irrational, which, whether it be called the super-rational or the infra-rational or the contra-rational, is all the same thing. Beyond these limits is the absurd...And this absurd can only base itself upon the most absolute uncertainty. ${ }^{8}$

Unwilling to be constrained by rationality's borders, Unamuno is able to remain open to something like a faithful way of life (cf. Kant, 1998, B xxx). For him, "uncertainty, doubt, perpetual wrestling with the mystery of our final destiny...may be the basis of an ethic" (Unamuno, 1954, p. 261). ${ }^{9}$ In combination with Unamuno's desperate need not to be utterly annihilated, his preservation of uncertainty about what will actually happen when he dies is what makes it possible for him to attribute meaning to his life (cf. Baker, 1990, p. 47; Culpepper, 1961, p. 281). As we have seen, if he were absolutely certain of annihilation, he would be thoroughly convinced his life is pointless. So, his uncertainty about it provides an opportunity for him to act as though his life matters. There are at least two crucial, and not entirely unrelated, ways of doing this.

First, even if it seems unlikely that death will lead to an unending flow of experience that is continuous with the personal consciousness of ordinary mortal life, the essential task for each of us is to live like we deserve to carry on. Paraphrasing Étienne Pivert de Senancour, Unamuno (1954, p. 268) states, "If it is nothingness that awaits us, let us make an injustice of it; let us fight against destiny, even though without hope of victory; let us fight against it quixotically." Like a Don Quixote mixed with Dylan Thomas, ${ }^{10}$ Unamuno advocates a contra-rational refusal to go quietly, even though such a refusal will not change the facts of one's situation (cf. Cummings, 2017, p. 141). Every individual is somewhat unique, and Unamuno thinks it would be a shame-maybe even a crime-if the universe were just snuffing out each unique perspective one by one. His response to such a thought is to fight to be more unique, more irreplaceable, so the injustice of exterminating him, and the

\footnotetext{
${ }^{8}$ Although he does not feel it necessary to make a sharp distinction in this passage, Unamuno (much like Kierkegaard, as I argue elsewhere [see e.g. Buben, 2013]) clearly gravitates toward the contra-rationalist or anti-rationalist approach to religious matters, such as the immortality of the soul. In discussing immortality specifically, he says, "It is no use seeking to force ourselves to consider as super-rational what clearly appears to us to be contra-rational" (Unamuno, 1954, p. 78; cf. pp. 65, 73-77, 263).

${ }^{9}$ There has been a long history of debate amongst Unamuno commentators as to whether his uncertainty and doubt could be the foundation for a genuinely Christian faith. For a helpful overview of this debate, see Armand F. Baker (1990, pp. 37-40). Although this is not my most pressing concern at present, given his similarities with Kierkegaard (and to a lesser degree, Pascal [cf. Baker, 1990, p. 42]) when it comes to the relationship between faith and reason, I am inclined to side with those who do not see Unamuno as completely divorced from Christian faith (even if the situation is complicated).

${ }^{10}$ The latter's famous poem says, "Do not go gentle into that good night. Rage, rage against the dying of the light" (Thomas, 2016, p. 193).
} 
corresponding indictment of the universe, will be greater. You should "Act so that in your own judgment and in the judgment of others you may merit eternity, act so that you may become irreplaceable, act so that you may not merit death" (Unamuno, 1954, p. 263). What Unamuno seems to have in mind here is something like Christian service to others, except the idea is that the more others depend on us and value our contributions to their lives, the worse it will be if the universe permanently takes us away. This indispensability becomes a kind of argument for not taking us away.

Importantly, the kind of service to others Unamuno recommends is not reserved for the religious or political elite and can be engaged in regardless of one's occupation or station in life. Even the shoemaker can make himself so indispensable that others will see his death as a great injustice-e.g. by caring so deeply for their foot-related worries that they can be free to focus on the deeper questions in their lives (see Unamuno, 1954, pp. 273-274). Not many people see their work like this, almost as a religious calling; in most cases we do the bare minimum to get paid. By focusing in this way on how we go about whatever it is we happen to be doing, Unamuno thinks it is possible to attribute a hint of meaning to our lives even if all the signs suggest we are approaching utter destruction and meaninglessness. ${ }^{11}$ At least we will be worthy of more if the signs turn out to be wrong.

His notion of a life that emphasizes "how" over "what" already suggests some important overlap with Kierkegaard's method of making meaning, but this is not the only relevant point of connection between them. ${ }^{12}$ Unamuno's other way of acting as though his life matters involves struggling to respond to his reasonable doubts about personal immortality with desire and hope, instead of "resignation" or agnosticism. Unamuno (1954, pp. 266-268) can understand those who believe personal immortality does not have reason and evidence on its side, but he simply cannot relate to those who abandon desire for it (even if they still harbor hopes for some "shadow of immortality"). In fact, Unamuno calls the failure to desire immortality "wicked," and he is not the first to make this kind of assessment. Kierkegaard's pseudonym Johannes Climacus, whose writings were very familiar to Unamuno (see Evans, 2013, p. 97), also suggests that such failure might be an indication of a character flaw or moral failing.

In Concluding Unscientific Postscript to "Philosophical Fragments," Climacus claims that "the way of the ethical becomes exceedingly long.... The more profoundly one makes it, the more one has to do"; it lasts "as long as life lasts" (Kierkegaard, 1992, pp. 162-163). In this context, "the ethical" is all about the

\footnotetext{
11 There are, of course, some limits to what counts as acceptable work. Some occupations are more obviously connected to the well-being of others, and some are just plain evil (see Unamuno, 1954, pp. 271-272). Michael A. Weinstein (1976, p. 50) claims these caveats indicate Unamuno is not fully committed to this "religious duty" approach to work, but this is a fairly speculative claim that is not obviously supported by the text.

${ }^{12}$ In the discourse, "At a Graveside," for example, Kierkegaard (1993) contrasts common clichés and other somewhat uncritical, public ideas about death with the personal and anxious lessons that can be learned from "the earnest thought of death." Among other things, he argues that paying sincere attention to the uncertainty surrounding death's "when" leads one to focus less upon what one accomplishes in life, and more on how one lives, because accomplishment requires time that cannot be guaranteed.
} 
cultivation of subjective selfhood - an individual determination and appropriation of ideals and activities that should be differentiated from the sort of lazy and unreflective public habits of thought and action that normally dictate our daily lives. A person's life can certainly end before this cultivation is complete, but no one should ever feel it is complete before dying: "To be finished with life before life is finished with one is not to finish the task at all" (Kierkegaard, 1992, p. 164). In other words, the forging of a proper subjective self is the project that should keep each of us busy throughout lives of any duration, even if nothing else does.

When it comes to the question of the possibility of immortality, Climacus' interest in becoming subjective makes him worry more about "how he, existing, is to conduct himself in expressing his immortality, whether he actually does express it, and for the time being is content with this task, which can easily be sufficient for a person's lifetime, since it is to be sufficient for an eternity" (Kierkegaard, 1992, p. 177; cf. pp. 201-202). It just does not matter all that much whether immortality is possible if one is incapable of sustaining a worthwhile existence (cf. Kierkegaard, 1992, p. 176). As one commentator puts it, to express my immortality well "requires me to determine whether my character is centered on something that will be eternally worthwhile - an aim worth pursuing forever...I need to find in my personality and my individual way of pursuing meaning something...that I can embrace eternally" (Wrathall, 2015, pp. 435-436). Each of us has to answer the very personal question, "am I suited for immortality?" (Wrathall, 2015, p. 434). A negative answer does not imply that I should surrender the desire for immortality, but it does suggest something unseemly about the state of my own existence and the value of the activities that define it. ${ }^{13}$

Just like Climacus, Unamuno sees life as an opportunity to take self-ownership and mold oneself into something unique and worthwhile (cf. Evans, 2013, p. 100). According to Hugo Culpepper (1961, pp. 286-287; cf. pp. 284, 294-295), Unamuno has "a view of the person as being produced by life and therefore as being in process of formation up to one's death....the end of life is to make for one's self a sou1. Man comes to the end of life with his self being formed. He passes through death to a life beyond which is in keeping with what he has become thus far." Giving up on the desire for personal immortality means giving up on the self one has spent an entire lifetime working on, the self that is the sole locus of meaning for Unamuno. More specifically, it means giving up on the project of self-development, which has the potential to generate meaning indefinitely (yet another point of agreement with Climacus). The immortality Unamuno (1954, p. 229) longs for consists of "a continual discovery of the Truth, a ceaseless act of learning involving an effort which keeps the sense of personal consciousness continually active." If I do not fashion a self that I want to continue cultivating throughout life and even beyond death, then I simply have not done a very good job of self-cultivation.

\footnotetext{
13 See Buben (2019) for a more thorough treatment of the views of Climacus discussed in the preceding paragraphs.
} 


\section{Running afoul of Nietzsche}

While Unamuno's outlook on preparing oneself for immortality clearly has a lot in common with Kierkegaard's, this is not so much the case when it comes to his other proto-existentialist precursor. The easiest thing to say here is that Nietzsche would probably see in Unamuno just another Kant, Pascal, or Socrates from Plato's Phaedo. ${ }^{14}$ Like these earlier figures, Unamuno certainly seems both critical of life that ends in annihilative death, and led by his criticisms into desiring a postmortem afterlife. It is not that Unamuno is so caught up in the old metaphysical fantasies of everlasting life, which Nietzsche so mercilessly mocks; ${ }^{15}$ whatever he ultimately hopes for, Unamuno has his fair share of doubts about all of that. What would seem to drive a lasting wedge between them is that Unamuno has such a hard time accepting a life that cannot give him exactly what he wants. Whereas Nietzsche (see e.g. 1990a, "Reason' in Philosophy"/Sect. 6) looks to affirm his existence-including its limitations and so-called "shortcomings"-in passionate creativity, Unamuno cannot seem to get over his disappointment at the thought that his personal being will probably have a permanent conclusion. If my speculative application of the former's ideas to a thinker he never had the chance to encounter is accurate, I believe Nietzsche's (1990b, Sect. 5) ultimate conclusion about Unamuno would be that, like Pascal, the Spaniard's strength-his will to affirm his existence-has been sapped and "depraved by his Christianity."16

But even though Unamuno is undeniably another "dreamer of immortality" (to use Nietzsche's [1997a, Sect. 211] expression) in some sense, ${ }^{17}$ it does not mean that this Nietzschean critique is entirely fair. What sets Unamuno apart from Kant, Pascal, Socrates from Plato's Phaedo, and most understandings of Christianity is that his hope for future life is not so thoroughly predicated on the perceived shortcomings of ordinary mortal life. Obviously, Unamuno sees annihilative death as a serious shortcoming (even an injustice), and he is not insensitive to life's "ills," but overall, he is actually quite supportive of life in the world. The sort of immortality

\footnotetext{
${ }^{14}$ He chastises these figures throughout his work, but some extremely relevant representative passages can be found in Nietzsche (1990a, "The Problem of Socrates," "Reason' in Philosophy"/Sect. 6; 1997b, $3^{\text {rd }}$ essay/Sect. 17; 2001, Sect. 340). When it comes to immortality and the value of mortal life, what Nietzsche seems to have in mind are ideas such as Blaise Pascal's (2005, S680/L418) famous "Wager" and Immanuel Kant's (1998, A 810-813/B 838-841) "Highest Good" and the corresponding postulates of freedom, God, and immortality. Each of these ideas, in its own way, belittles mortal life if there is not an afterlife to come.

15 Nietzsche is frequently critical, throughout his work, of all sorts of promises about the afterlife and immortality. See e.g. Nietzsche (1968, Sect. 224; 1990b, Sects. 15, 18, 38, 42-43; 1997a, Sect. 72; 1997b, $1^{\text {st }}$ essay/Sect. 14; 2001, Sect. 344; 2006, "On the Hinterworldly").

16 For Nietzsche, one other sign of Christianity's corrupting influence would be Unamuno's democratic view of the inherent uniqueness of each human being, which he uses to help make his point about the injustice of being annihilated. Nietzsche (see e.g. 1990b, Sect. 43; 1997b, $3^{\text {rd }}$ essay/Sect. 22) does not think the vast majority of humans are particularly special or worth preserving.

17 Unamuno (1954, p. 232) briefly takes the image of dreaming in another, similarly problematic (from Nietzsche's perspective), direction when he considers whether life in the world is a dream, and death an awakening in "a transcendent reality to live the life beyond" (Culpepper, 1961, p. 285). This is precisely the kind of claim Nietzsche derides when made by other thinkers.
} 
he craves would be both bodily and continuous in many ways with the life he is living up until the moment of death. ${ }^{18}$ From his perspective, the desire for more life springs from a deep appreciation for the worldly existence he already has and the self he is using it to cultivate. It would be difficult to find a similar appreciation in the earlier figures Nietzsche picks on. I do not mean to suggest that this important difference should spare Unamuno from all of Nietzsche's attacks, but the latter should at least recognize a certain affinity in their shared lust for life.

In fact, Unamuno seems to think it is Nietzsche who comes up short in the "lust for life" department. He turns out to be one of those "wicked" individuals who allow reason to persuade them to abandon desire for personal immortality and replace it with some pathetic "shadow of immortality." According to Unamuno's (1954, pp. 50-51; cf. p. 231) critical account of Nietzsche:

His heart craved the eternal All while his head convinced him of nothingness...Bursting with his own self, he wished himself unending and dreamed his theory of eternal recurrence, a sorry counterfeit of immortality...And there are some who say that his is the philosophy of strong men! No, it is not. My health and my strength urge me to perpetuate myself. His is the doctrine of weaklings who aspire to be strong, but not of the strong who are strong. Only the feeble resign themselves to final death and substitute some other desire for the longing for personal immortality. In the strong the zeal for perpetuity overrides the doubt of realizing it, and their superabundance of life overflows upon the other side of death. ${ }^{19}$

So, from Unamuno's point of view, Nietzsche is the "dreamer" who invented an outlandish metaphysical scenario because he could not accept going entirely out of existence. In Nietzsche's case (which differs from Unamuno's dreaming of immortality), if he only had the strength to continue the inexhaustible project of selfdevelopment, he would not so easily have given up hope for its continuation, and the invention of the eternal recurrence would not have felt so necessary. ${ }^{20}$ Despite Nietzsche's exuberant claims about affirmation and creative self-cultivation, Unamuno thinks he simply does not have the will to keep it up forever. There are, after

\footnotetext{
18 Michael Candelaria (2012, pp. 47-50) claims that one of Unamuno's main reasons for wanting immortality is that "earthly existence" is "vain." I cannot see much evidence in The Tragic Sense of Life (outside of the brief discussion of life as a dream) that suggests Unamuno thinks earthly existence is, in itself, vain. Rather, what makes earthly existence appear vain is the prospect of utter personal annihilation. If immortality awaits us, then earthly life is just part of our continuously meaningful existence.

19 Lars Bergström (2013, p. 176n28) complains that Unamuno does not thoroughly explain why eternal recurrence is "a sorry counterfeit of immortality." Given everything Unamuno says about the experientially continuous personal immortality he really wants in comparison with the "shadows of immortality," I do not think it is any mystery why Unamuno is unimpressed with eternal recurrence. Like other "shadows," eternal recurrence lacks experiential continuity.

20 This is another point of contention with Candelaria (2012, p. 56), who apparently sees Nietzsche-as diagnosed by Unamuno in the quotation above - as an example of failure to believe in personal immortality, rather than failure to desire it. I think the quotation clearly indicates that Nietzsche's problem is failure to maintain his desire in the face of overwhelming reason and evidence. There is no doubt he also failed to believe, but lack of belief is not Unamuno's concern in his discussions of Nietzsche in The Tragic Sense of Life.
} 
all, several passages in Nietzsche's (see e.g. 2006, “On Free Death") writings about the importance of coming to terms with, and even embracing, death when one's creative potency begins to fade.

However, just as the Nietzschean critique of Unamuno was slightly off target, it is probably fair to say that Unamuno's assessment of Nietzsche is not exactly a direct hit either. Unamuno's (cf. 1954, pp. 100-101) very literal interpretation of the eternal recurrence idea, which lines up almost perfectly with one controversial contemporary reading, is particularly problematic. ${ }^{21}$ As I argue in greater detail elsewhere (Buben, 2020), this reading is flawed in two ways. First, the textual evidence provided to support it is questionable at best. In Nietzsche's published work, the eternal recurrence is mostly put in hypothetical and allegorical terms (cf. Anderson, 2017, Sect. 6.3). In The Gay Science, which contains his first and most famous expression of the idea, Nietzsche (2001, Sect. 341) poses the following scenario:

What if some day or night a demon were to steal into your loneliest loneliness and say to you: "This life as you now live it and have lived it you will have to live once again and innumerable times again; and there will be nothing new in it, but every pain and every joy and every thought and sigh and everything unspeakably small or great in your life must return to you, all in the same succession and sequence..." Would you not throw yourself down and gnash your teeth and curse the demon who spoke thus? Or have you once experienced a tremendous moment when you would have answered him: "You are a god, and never have I heard anything more divine."

The eternal recurrence also comes up in Nietzsche's unpublished musings, which were maybe never intended to see the light of day, and in Thus Spoke Zarathustra (e.g. in the sections "On the Vision and the Riddle" and "The Sleepwalker Song"), a fictional tale full of metaphor, poetry, and symbolism. It is far from obvious whether the reader is meant to take from these fascinating, but rather ambiguous, examples some indication of Nietzsche's actual metaphysical views. Some commentators even think we can "lay to rest any notion that Nietzsche wants to defend the idea of a recurring cosmic cycle as a theory about the actual nature of the universe," because "there are issues about what exactly Nietzsche is doing with these arguments" (Moore, 2006, p. 319).

In addition to the evidentiary concerns, the more important problem with the literal reading Unamuno subscribes to is that it implausibly makes Nietzsche into a hypocrite. As I mentioned above, Nietzsche ruthlessly ridicules outlandish metaphysical scenarios meant to provide comfort to people nervous about their mortality. It simply does not make sense that he would intentionally and unironically turn around and propose his very own comforting fantasy, and it is not a very charitable reading of his ideas to suggest he contradicted himself unwittingly. The more

\footnotetext{
21 Paul S. Loeb is the main contemporary champion of this reading, which he defends in numerous publications. For a brief example, see Loeb (2017, pp. 86-87, 90-99). Despite the interpretive similarity, Unamuno and Loeb actually appraise Nietzsche's eternal recurrence idea in very different ways. While Unamuno is highly critical, Loeb is more supportive.
} 
sensible and fair interpretation is that Nietzsche means the eternal recurrence idea as a kind of thought experiment, not to be taken literally, but useful for testing how affirmatively disposed one is toward the self one has become and the life that has been spent cultivating it. At the end of the famous demon aphorism from The Gay Science, Nietzsche (2001, Sect. 341) wonders, "how well disposed would you have to become to yourself and to life to long for nothing more fervently than for this ultimate eternal confirmation and seal?" If running it all back again, over and over, in every minute detail sounds good to you (whether or not you think it will actually happen), then you have passed the test. Seen in this way, Unamuno is wrong to suggest introducing the eternal recurrence is proof Nietzsche is chasing some "shadow of immortality."

On the other hand, he is not necessarily wrong to suggest Nietzsche might be a little too willing to surrender his life when there is still meaningful work left to be done. Like Unamuno, Nietzsche wants to encourage a strong and passionate appreciation for life, but in one notable sense, he does not seem to want it as much as Unamuno. Nietzsche (2006, "On War and Warriors") is preoccupied with the quality of life and is somewhat indifferent as to its length: "What matters living long! Which warrior wants to be spared!" This is not to say that he necessarily wants his life to end or thinks mortality generates some sort of essential value in his life; so long as life is lived in the right way, death, longevity, and mortality are just kind of irrelevant (cf. Stambler, 2010, pp. 17-18; Steinmann, 2017, pp. 187-188). Given Unamuno's rather intense interest in continuing to work on himself, he obviously sees these issues as very relevant, but this difference between them is not as profound as it might seem when he is taking Nietzsche to task. After all, neither of them is actually opposed to personal immortality in itself. But if Unamuno would have little tolerance for the "take it or leave it" attitude I attribute to Nietzsche, he would have far more serious concerns about the decidedly "leave it" views of the immortality curmudgeons.

\section{Giving up on oneself}

Before finally getting into the weeds of Unamuno's hypothetical response to immortality curmudgeons, one other important question remains: how have his ideas been treated in the desirability of immortality debate? His famous "I do not want to die...I want to live for ever and ever and ever" declaration is quoted occasionally by thinkers on both sides of the debate, but especially by those on the curmudgeonly side. It is, after all, a succinct and fairly straightforward example of the view naysayers about worthwhile immortality mean to undermine. Unfortunately, beyond this superficial exemplary role, Unamuno's more nuanced ideas related to the desirability of immortality are rarely given thorough attention. ${ }^{22}$ One notable exception can be found in the closing pages of Bernard Williams' groundbreaking curmudgeonly

\footnotetext{
22 For example, both Steven Luper-Foy (1993, p. 269) and Aaron Smuts (2011, p. 134) begin articles by quoting the famous passage, although they have little to say about Unamuno after that.
} 
analysis, "The Makropulos Case: Reflections on the Tedium of Immortality." After quoting Unamuno's declaration, and distinguishing its message from other views discussed earlier in his paper, Williams (1993, pp. 91-92) appears to settle on an interpretation that suggests Unamuno simply wants to exist for the sake of mere existence. This is a position that Williams finds hard to accept or even understand: "his desire to remain alive extends an almost incomprehensible distance."

What he finds especially troubling is Unamuno's preference for the eternal torments of hell over personal extinction. While I can sympathize with his struggle to wrap his mind around that particular claim, I am not sure Williams' overall reading is the most accurate or charitable one available. According to Williams (1993, p. 83), what makes life worth living are "categorical desires"; they define who we are and give us reason to go on, even if doing so means we will have to endure suffering. They are distinct from the less interesting desires we only have on the condition we happen to exist (e.g. we do not generally desire to go on living in order to get more water or oxygen, but we certainly want more of those substances if we are still alive). In explaining the importance of this distinction, Williams (1993, p. 77) considers rational suicide: "a man might consider what lay before him, and decide whether he did or did not want to undergo it. If he does decide to undergo it, then some desire propels him on into the future, and that desire at least is not one that operates conditionally on his being alive, since it itself resolves the question of whether he is going to be alive. He has an unconditional, or...categorical desire." The problem with categorical desires, as Williams (see e.g. 1993, pp. 82, 87) understands them, is that no one can maintain a consistent personal identity (i.e. continue to be the self one wants to be when one wants to go on living) forever without exhausting them. In the eventual absence of categorical desires, Williams cannot believe Unamuno would really prefer to suffer endlessly just so he can prolong an empty, repetitive, and boring existence. Why endure pointless suffering if personal annihilation is an option?

The mistake I see in Williams' account of Unamuno's position gets back to the discussion of Kierkegaard's Climacus and the comparison I made with Unamuno. Like Climacus, Unamuno believes there is at least one categorical desire that cannot be exhausted: the project of self-cultivation (which, in Unamuno's case, partially involves making oneself indispensable to others). Because a thoughtful and responsible person can always rely on this project to give meaning to life, by Williams' own logic it is not so ridiculous to go on suffering. Williams obviously does not consider this kind of inexhaustible categorical desire, and he might even complain that too much self-development is somehow incompatible with his very strict standard of personal identity, but several thinkers have made strong cases in favor of rejecting this standard (see e.g. Chappell, 2007, pp. 35-39). ${ }^{23}$

\footnotetext{
${ }^{23}$ Connie S. Rosati (2013, p. 369) suggests a different approach to defending Unamuno from Williams. She seems to accept his basic reading of Unamuno's declaration, before going on to champion the idea that mere existence is in itself a legitimate object of feelings of value and desire. I am extremely supportive of her general argument against Williams' (see 1993, p. 78) position, even if I think her brief comments about Unamuno fail to dig deep enough into his other relevant views. Roughly, Rosati (2013, Sect. 3.1) holds that while Williams thinks our affection for our own individual lives depends on our having categorical desires, categorical desires actually arise from our more fundamental love of our own lives. We value ourselves as beings that are capable of valuing things, so we give ourselves things to value-e.g. projects.
} 
What emerges from this brief description of the relationship between Williams and Unamuno is the sense that the former is not someone who sees a lot of potential in individual human beings. Williams seems to think we would be doing quite well if we are able to keep life worth living over the course of a typical human lifespan. After that, he believes it gets easier and easier for us to grow weary of personal existence. This is no mild Nietzschean indifference, but a full-blown pessimism about the prospects for meaning in radically extended life and immortality. When it comes to this type of curmudgeonly pessimism, Williams is probably at the high end of the spectrum, but insofar as curmudgeons in general think a truly immortal life could not be worth living (see e.g. May, 2009, chapter 2; Smuts, 2011; Scheffler, 2013, Lecture 3), he is not alone in failing to recognize the full value of the kind of self-making project Unamuno recommends. At some point or another in an extended lifetime, they will all give up on themselves (by which I mean they, by their own admission, will cease to see value in their lives), or at least they assume they will. This is the greatest sin against oneself, according to Unamuno; relinquishing a fundamental human task with indefinite potential after some finite amount of time suggests an impoverished sense of who one is or could be. However, what Unamuno does not explicitly discuss, and what I would argue makes curmudgeons far more problematic on his view than someone like Nietzsche, is the attack against the desirability of immortality itself. Nietzsche attacks the desire for immortality (mostly because it is often predicated on disparaging ordinary mortal life in the world), and this is bad enough, but to attack its desirability, i.e. the (potential for) value of immortality, is an additional transgression that shows an even more profound lack of faith in one's capabilities for growth and improvement. ${ }^{24}$

Setting Nietzsche aside, then, if Unamuno had encountered the contemporary curmudgeonly tendency, I suspect he would diagnose it as an even more acute form of the despair he sees in those who feel compelled by reason and evidence to abandon hope for personal immortality (often exchanging it for the more modest comforts of one of its impersonal "shadows"). ${ }^{25}$ These poor souls "resign [themselves] to fate" and say, "since we are not immortal [in the personal sense], do not let us want to be so" (Unamuno, 1954, p. 50). There is certainly a hint of "sour grapes" and bad faith in this kind of claim, in denying that one wants something only when it appears one cannot have it anyway, but the curmudgeons seem to take the "sour grapes" a step further. It is as though they say, "since we are not immortal, do not let us want to be so, and in fact, immortality is not really worth wanting in the first place." This addition becomes necessary as curmudgeons, rather than merely resigning themselves to mortality, lash out argumentatively in "hostility" and "spite," to use Unamuno's terms. From his perspective, it looks like they are personally bitter

\footnotetext{
${ }^{24}$ In case this distinction is unclear, here is an illustrative example: I can recognize the benefits (i.e. the desirability/value/worth) of having a new car without actually wanting/desiring a new car myself. I understand the convenience of car ownership, but perhaps I enjoy using the public transportation services in my city, or I do not want to contribute to air pollution.

25 I would not say the curmudgeons are defined by retreat into the "shadows of immortality." Although some of them (e.g. May, 2009, pp. 81-82, 91-93) do seek out comfort in the thought of some kind of impersonal preservation, this is not a necessary feature of being a curmudgeon.
} 
about being unable to hope for something more, and also like they inflict their bitterness on those who dare to preserve such hope for themselves. This might not be an entirely fair assessment of the motivations of every curmudgeon, and I do not want to follow Unamuno too far down the psychologizing rabbit hole, but it does not seem too outrageous to believe there might be a kernel of truth to it in at least some cases. A charitable interpretation would not simply assume that curmudgeons have such bitter motivations when they produce arguments against the desirability of immortality, but I think it is worth mentioning that this is a possibility self-reflective curmudgeons should be on guard against.

\section{Conclusion}

Of all the thinkers associated with the existentialist tradition, Unamuno is the most openly desirous of personal immortality. His intense expression of desire for it, despite his awareness that reason and evidence cast doubt upon its possibility, is almost certainly what makes his views on the matter more susceptible to criticism than those of Kierkegaard and Nietzsche. However, what Unamuno has in common with his more northerly existentialist comrades - a focus on the cultivation of selfhood in an uncertain/indeterminate world-is ultimately what makes him a compelling (albeit underappreciated) contributor to the desirability of immortality debate. Furthermore, when it comes to criticism, Unamuno demonstrates that he can give as good as he gets. He knows that if he wants to see his personal consciousness persist eternally, he will need to envision a self capable of perpetual progress, and this will turn out to be precisely what immortality curmudgeons have a hard time doing (as they readily admit). As if in anticipation of their arguments, Unamuno seems to go on the offensive as he raises troubling questions that could be posed to them about the nature of their approach to life and their polemical motivations. While I generally prefer a more even-handed construal of the pessimists who follow Williams, it is helpful to keep in mind that the curmudgeonly tendency of these thinkers may not always come from a place of neutral intellectual curiosity. ${ }^{26}$

Open Access This article is licensed under a Creative Commons Attribution 4.0 International License, which permits use, sharing, adaptation, distribution and reproduction in any medium or format, as long as you give appropriate credit to the original author(s) and the source, provide a link to the Creative Commons licence, and indicate if changes were made. The images or other third party material in this article are included in the article's Creative Commons licence, unless indicated otherwise in a credit line to the material. If material is not included in the article's Creative Commons licence and your intended use is not permitted by statutory regulation or exceeds the permitted use, you will need to obtain permission directly from the copyright holder. To view a copy of this licence, visit http://creativecommons.org/licen ses/by/4.0/.

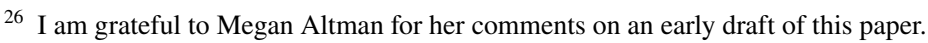




\section{References}

Agatonović, M. (2018). The case of transhumanism: The possibility of application of Nietzsche's ethics and critique of morality today. Philosophy and Society, 29(3), 429-439.

Anderson, R. L. (2017). Friedrich Nietzsche. Stanford Encyclopedia of Philosophy. https://plato.stanford. edu/entries/nietzsche/.

Ariso, J. M. (2017). Unamuno's mirror-games: On the seeming omnipotence and meaningfulness of writing in the grammatical void. Linguistic and Philosophical Investigations, 16, 90-103.

Baker, A. F. (1990). Unamuno and the religion of uncertainty. Hispanic Review, 58(1), 37-56.

Bergström, L. (2013). Death and eternal recurrence. In B. Bradley, F. Feldman, \& J. Johansson (Eds.), The Oxford handbook of philosophy of death (pp. 167-185). Oxford University Press.

Bradley, B. (2015). Existential terror. The Journal of Ethics, 19, 409-418.

Buben, A. (2013). Neither irrationalist nor apologist: Revisiting faith and reason in Kierkegaard. Philosophy Compass, 8(3), 318-326.

Buben, A. (2019). Kierkegaard and the desirability of immortality. In A. Buben, E. Helms, \& P. Stokes (Eds.), The Kierkegaardian mind (pp. 351-361). London: Routledge.

Buben, A. (2020). The dark side of desire: Nietzsche, transhumanism, and personal immortality. Southern Journal of Philosophy. https://doi.org/10.1111/sjp.12393.

Candelaria, M. (2012). The revolt of unreason: Miguel de Unamuno and Antonio Caso on the crisis of modernity. Rodopi.

Chappell, T. (2007). Infinity goes up on trial: Must immortality be meaningless? European Journal of Philosophy, 17(1), 30-44.

Culpepper, H. (1961). Immortality and modern thought: A study of Miguel de Unamuno. Review and Expositor, 58(3), 279-295.

Cummings, A. (2017). Don Quixote meets Mr. Gradgrind: A neglected proof for immortality. Logos: A Journal of Catholic Thought and Culture, 20(1), 135-156.

Evans, J. E. (2013). Miguel de Unamuno's quest for faith: A Kierkegaardian understanding of Unamuno's struggle to believe. Pickwick.

Fischer, J. M. (2009). Why immortality is not so bad. In Our Stories: Essays on Life, Death, and Free Will (pp. 79-92). Oxford University Press. Reprinted from International Journal of Philosophical Studies, 2 (1994), 257-270.

Franz, T. R. (1980). Parenthood, authorship, and immortality in Unamuno's narratives. Hispania, 63(4), $647-657$.

Kant, I. (1998). Critique of pure reason, P. Guyer and A. W. Wood (Trans.). Cambridge University Press.

Kierkegaard, S. (1992). Concluding unscientific postscript to Philosophical Fragments, Vol. 1, H. V. Hong and E. H. Hong (Trans.). Princeton University Press.

Kierkegaard, S. (1993). Three discourses on imagined occasions, H. V. Hong and E. H. Hong (Trans.). Princeton University Press.

Loeb, P. S. (2017). Nietzsche's transhumanism: Evolution and eternal recurrence. In Y. Tuncel (Ed.), Nietzsche and transhumanism: Precursor or enemy (pp. 83-100). Cambridge Scholars. Reprinted from The Agonist, IV(II), (2011).

Luper-Foy, S. (1993). Annihilation. In J. M. Fischer (Ed.), The metaphysics of death (pp. 269-290). Stanford University Press. Reprinted from The Philosophical Quarterly, 37(148), (1987), 233-252.

May, T. (2009). Death. Acumen.

Metz, T. (2003). The immortality requirement for life's meaning. Ratio, 16(2), 161-177.

Moore, A. W. (2006). Williams, Nietzsche, and the meaninglessness of immortality. Mind, 115, 311-330.

Nietzsche, F. (1968). The will to power, W. Kaufmann \& R. J. Hollingdale (Trans.). Vintage.

Nietzsche, F. (1990). Twilight of the idols (a) and The Anti-Christ (b), R. J. Hollingdale (Trans.). Penguin. Nietzsche, F. (1997a). Daybreak, R. J. Hollingdale (Trans.). Cambridge University Press.

Nietzsche, F. (1997b). On the genealogy of morality, C. Diethe (Trans.). Cambridge University Press.

Nietzsche, F. (2001). The gay science, J. Nauckhoff (Trans.). Cambridge University Press.

Nietzsche, F. (2006). Thus spoke Zarathustra, A. Del Caro (Trans.). Cambridge University Press.

Olivelle, P., trans. (2008). Upanișads. Oxford University Press.

Pascal, B. (2005). Pensées, R. Ariew (Trans.). Hackett.

Plato (2002). Five dialogues, 2nd ed., G. M. A. Grube (Trans.), revised by J. M. Cooper. Hackett. 
Rosati, C. S. (2013). The Makropulos Case revisited: Reflections on immortality and agency. In B. Bradley, F. Feldman, \& J. Johansson (Eds.), The Oxford handbook of philosophy of death (pp. 355-390). Oxford University Press.

Scheffler, S. (2013). Death and the afterlife. Oxford University Press.

Schopenhauer, A. (1958). The world as will and representation, vol. 2, E. F. J. Payne (Trans.). The Falcon's Wing.

Smuts, A. (2011). Immortality and significance. Philosophy and Literature, 35(1), 134-149.

Stambler, I. (2010). Life extension - a conservative enterprise? Some fin-de-siècle and early twentiethcentury precursors of transhumanism. Journal of Evolution and Technology, 21(1), 13-26.

Steinmann, M. (2017). "But what do we matter!" Nietzsche's secret hopes and the prospects of transhumanism. In Y. Tuncel (Ed.), Nietzsche and transhumanism: Precursor or enemy (pp. 172-190). Cambridge Scholars.

Thomas, D. (2016). The collected poems of Dylan Thomas. Weidenfeld \& Nicholson.

Unamuno, M. de (1954). Tragic sense of life, J. E. Crawford Flitch (Trans.). Dover.

Weinstein, M. A. (1976). Unamuno and the agonies of modernization. The Review of Politics, 38(1), 40-56.

Williams, B. (1993). The Makropulos Case: Reflections on the tedium of immortality. In J. M. Fischer (Ed.), The metaphysics of death (pp. 73-92). Stanford University Press. Reprinted from Problems of the Self. Cambridge University Press, 1973, pp. 82-100.

Wisnewski, J. J. (2005). Is the immortal life worth living? International Journal for Philosophy of Religion, 58, 27-36.

Wrathall, M. A. (2015). Trivial tasks that consume a lifetime: Kierkegaard on immortality and becoming subjective. Journal of Ethics, 19, 419-441.

Publisher's Note Springer Nature remains neutral with regard to jurisdictional claims in published maps and institutional affiliations. 